\title{
A Ministry/Khiläfa of Radical Kinship: The Theological Educator and Student as Interreligious Ally
}

\author{
Scott C. Alexander
}

\begin{abstract}
Inspired by the lyrics of Florence + the Machine's riff on the story of the biblical (anti-) heroine Delilah (Judges 13-16), this paper seeks to contribute to the conversation on the nature of the emerging field of interreligious studies through the lens of the struggle to be an interreligious ally. It argues that conversations about the telos/teloi of interreligious studies lie at the heart of broader discussions concerning the shifting orientations of theological education in general in the first few decades of the twentyfirst century. After exploring some of the challenges involved in aspiring to be an interreligious ally (specifically the intersectional dynamics around race, gender, and sexual orientation), the paper pursues an original exegesis of Qur'an 2:30-33 as the basis for an exercise in comparative Christian-Muslim theology. It proposes "ministry/khiläfa of radical kinship" - especially in the form of becoming an interreligious ally-as one possible paradigm for thinking about the telos of interreligious studies and as a possible organizing principle for emerging interreligious pedagogies.
\end{abstract}

It's a different kind of danger And the bells are ringing out, And I'm calling for my mother As I pull the pillars down. It's a different kind of danger And my feet are spinning around; Never knew I was a dancer 'til Delilah showed me how

Florence + the Machine 


\section{Introduction}

This epigraph is taken from the refrain of an indie rock tune. It's the tune that actually inspired me to write this distinctly personal essay. It focuses on aspects of my own journey as a theological educator deeply engaged in the challenging and rewarding work of interreligious pedagogy in the hope that others may find some elements of my own story relevant to theirs. I'll have more to say about the significance of this song in my concluding remarks. For now, I simply beg your indulgence as I lean into the musical nature of my original inspiration, and employ a musical metaphor-albeit from an entirely different genre-for thinking about the three main sections of this essay.

It opens with a "prelude" in the shape of a personal testimonial. The testimonial is about my aspiration to be an interreligious and intercultural ally; it is about the indispensable nature of this aspiration to my vocation as both a Christian and a theological educator; and it is about some of the dangers and pitfalls of such an aspiration. This prelude is designed to provide the backdrop for two subsequent "movements" and a finale, each of which explores issues that fall within the broader focus of this volume on the praxes of interreligious pedagogy. The first is built around a rather brash ethereal flourish, having to do with the very telos of theological education in a time of tremendous cultural and institutional flux and change. The second movement, significantly more subdued and earthy, has to do with conceptualizing the aspiration to be an ally as a ministry/khiläfa of radical kinship. ${ }^{1}$ It also considers the practical implications of exercising this ministry/khiläfa both within and outside the classroom. The finale is a slightly underdeveloped and somewhat atonal attempt to synthesize the registers of the two preceding movements by arguing that one of the central dynamics of the ministerial identity formation of the theological educator and the theology student of the twenty-first century will involve a revolutionary turn toward a full embrace of liminality and the potential for "chaordic" leadership in a ministry/khilāfa of radical kinship — especially in its interreligious modality.

About five years ago, I was invited to join a "secret group" on Facebook. The group was organized to give LGBTQ Muslims a "safe space" for sharing both the

1 I borrow this concept of "radical kinship" from the writings of Gregory Boyle, especially in his most recent book, Barking to the Choir: The Power of Radical Kinship (New York: Simon and Schuster, 2017). 
joy and the pain of trying to be, on the one hand, true to themselves, and on the other hand, true to their faith and its tradition of exacting moral uprightness. I hesitated to accept. By conventional standards, I fit neither into the category of "Muslim" nor "LGBTQ." When, for these reasons, I expressed my doubts about joining the group, the Facebook friend who invited me-a South Asian man studying in Europe-assured me that I would be warmly welcomed by the existing members. He made reference to what he knew about my credentials. He pointed out that I had a $\mathrm{PhD}$ in Islamic studies and had been teaching in the field for many years. He remarked about the number of Muslim Facebook followers I appeared to have, and said how impressed he was when he read my Facebook bio: "Catholic whose life has been immeasurably blessed by Islam and Muslims." Then he hit me with: "We need allies and you're the perfect ally." What he didn't know was that when he typed these words into his message window, he not only struck keys on a keyboard, but he also pushed just the right button. I agreed to join.

There was that word again: "ally." I must confess that, beyond the sentimental context of a few favorite wWII movies, it's a word that evokes an ambivalent reaction in me. It's one of those words like "befriend." On the surface, it seductively evokes an ethos of solidarity and relationship building. Just beneath, however, it harbors anywhere from a subtle to a bold resonance of crass selfinterest, at times even bordering on the sinister. Yet "ally" is a category into which, for most of my professional life in interreligious and intercultural studies and dialogue, I have either actively striven to be placed, or been blessed to have been reluctantly dragged.

I aspire to be an ally because, as a Christian, it is my sacred duty. Christian discipleship demands love of neighbor - not as cheap sentiment but as costly commitment. My faith teaches that one cannot hope to respond to the call of the Gospel unless one struggles to be in right relationship and moral solidarity with other members of the human family, especially the poor and the oppressed. In my own U.S. American context, and as an economically secure, heterosexual, cisgender male who- to use Baldwin's uniquely apt language"thinks himself white," this means I must strive to ally myself with those who are economically vulnerable, improperly served, individually or culturally misunderstood, stigmatized, minoritized, maligned, and even demonized by the very structures of white capitalist heteronormative "Christian" power and privilege I routinely enjoy.

I also seek to be an ally because I understand this aspiration to be central to the vocation of any theological educator. If, as I will argue below, the telos of theological education in the twenty-first century is to help nurture and sustain generations of transformational spiritual leaders committed to building 
communities of radical kinship, then the centrality of the aspiration to be an ally is non-negotiable. For theological educators and students whose social location is, like mine, one of relative power and privilege, there is no way to help orchestrate formative contexts for creative and life-giving ministerial praxis without being intentionally vulnerable and open to intellectual, spiritual, and moral transformation by students, colleagues, and broader publics with subaltern identities and experiences. For theological educators and students who are themselves subalterns, the demands of intersectional personal and professional development in the context of alliances with other subalterns, as well as with allies of privilege, is every bit as non-negotiable.

The many dangers and pitfalls of aspiring to be an ally are fairly well known. They are to be as constantly monitored in an ongoing process of self-reflection, as they are absolutely to be resisted as a basis for either self-congratulation or self-pity. They include the many ways of reinscribing one's own privileged agency at the expense of the agency of the those most affected by injustice: seeing others, for example, as "victims" in need of "help" and perceiving oneself as a "rescuer" or "savior." They include the difficulties of negotiating the psycho-spiritual tensions and ambiguities surrounding distinctions between personal sin and social sin, as one attempts to square the circle of discontinuities between individual identity and accountability, on the one hand, and group identity and accountability, on the other. They also include being perceived, rightly or wrongly, as inauthentic - as an interloper or wannabe who is either insecure in one's identity, deliberately attempting to hide one's true self from oneself and others, or some combination of both.

In my case, this has involved being perceived by various publics as: a "traitor" to Catholicism (or Christianity in general); a traitor to my bleached white immigrant blue-collar roots; a crypto-Muslim; a "good" white guy; a self-satisfied "double-belonger"; and a closeted gay man. Perhaps the most profoundly ironic of all is also the one that is far and away the most painful. It is to be accused of being a crypto-Islamophobe. I am placed in this latter category only very seldomly, and by those who are convinced that the combination of years of study of Islam - including the ability to read the Qur'an and hadith in the original Arabic-together with the fact that I have not converted (i.e., officially declared myself "Muslim") render me a living embodiment of the Western Christian/Orientalist rejection of Islam as an inferior or entirely false religion. I do not see myself at all in this light. Nonetheless, the light in which we see ourselves, and the light in which others see us, frequently and oftentimes sharply differ, with the truth usually lying somewhere along the uncharted spectrum in between. Thus, I am grateful when I am reminded that this is how some perceive me. Despite the fact that it saddens me deeply, I like to think 
I understand why people would harbor such profound misgivings about me. And although I continue to have my own serious misgivings about this rare accusation, I nonetheless deeply appreciate the challenge to think about the subtle ways in which my accusers may be right.

For reasons having to do with everything from my own Italian American upbringing in the 1960s and 1970s, to my abiding interest and yet still steep learning curve in U.S. American history (from Jamestown to Trump), to my seventeen years living on Chicago's Southside, among the most pressing, challenging, and exhilarating of "alliances" for me are those into which I have been invited by my Blackamerican sisters and brothers, ${ }^{2}$ so many of whom are also Muslims. It is in this context, more than in any other, that I have learned just how pathetic and even comical my aspirations to be an ally can sometimes be. I never cease to be surprised by the depth and extent of my privilege, and the nearly limitless ways I exercise this privilege with what can only be described as blissfully ignorant abandon. I have also come to realize that the very real intellectual, emotional, and spiritual discomfort I experience in this processall the anxiety, embarrassment, anger, and frustration - is, both in principle and fact, an affront to the cumulative and collective pain of my Blackamerican students, colleagues, friends, and associates. At the same time, however, I am aware that to the degree I cannot live with the built-in "adversities" of aspiring to be an ally, these adversities become formidable obstacles to my efforts, meager as they are. The key to dealing with these adversities, and thus the source of transformative grace in them, lies in the awareness that it is only to the extent that I am willing to own each and every one of my inadequacies

2 In this usage, I am adopting the apt neologism of Sherman Jackson, who rationalizes its coinage in his stunning theological history of Blackamerican Islam: "On the one hand, to speak simply of 'black Americans' as the counterparts of 'white Americans' is to strengthen the hand of those who wish to deny or hide white privilege. On the other hand, to speak of African Americans is to give short shrift to almost half a millennium of New World history, implying that Blackamericans are African in the same way that Italian Americans or Greek Americans are Italian or Greek. I emphatically recognize, wholly embrace, and celebrate the African origins of Blackamericans. But in my view, the force of American history has essentially transformed these erstwhile Africans into a new people. This is especially so with regard to their religious orientation. Of course, I could have opted for the hyphenated convention 'BlackAmerican.' But ... the point of the hyphenated American is that the right side of the hyphen assumes the responsibility of protecting the cultural, religious, and other idiosyncrasies of the left side. As Blackamericans have rarely if ever enjoyed this protection on a par with other ethnic Americans, it would be misleading, in my view, to cast blacks as just another hyphenated group in America" (emphasis mine). See Sherman A. Jackson, Islam and the Blackamerican: Looking Toward the Third Resurrection (New York: Oxford University Press, 2005), Kindle ed., loc 236-42 (print edition, 17). 
as an aspiring ally, that I can actually become an ally. Once I realize and accept my shortcomings, only then can the Master Builder employ me as just one of a myriad of fellow workers in the thoroughly divine adventure of building the Reign of Wholeness in a broken world. ${ }^{3}$

I began reflecting in earnest on the topic of exercising a ministry/khiläfa of radical kinship as an aspiring interreligious ally when I took part in a multistage project run by Ted Smith of Emory University. The project is entitled "Theological Education between the Times" with an intentional double entendre. On the one hand, "between the times" refers to the present moment of what can soberly be described as tectonic shifts in the landscape of graduate theological education. These shifts involve a number of diverse and intersecting changes from what once was. These include such phenomena as: the closing or consolidation of schools; declining enrollments; the eclipse of the MDiv as the most popular terminal professional degree; a steady rise in millennial self-identification as spiritual but religiously unaffiliated (i.e., as "nones"); the precipitous rise in the popularity and utility of online and other forms of distance learning; the increasingly unmanageable debt of graduates of theology

3 I draw this image of the "Master Builder" and the "worker" from the words of the late great Bishop of the Diocese of Saginaw, Michigan: Ken Untener. In a beautiful composition widely referred to as the "Oscar Romero prayer" and entitled "A Step along the Way," Untener writes: "It helps, now and then, to step back and take a long view. The kingdom is not only beyond our efforts, it is even beyond our vision. We accomplish in our lifetime only a tiny fraction of the magnificent enterprise that is God's work. Nothing we do is complete, which is a way of saying that the kingdom always lies beyond us. No statement says all that could be said. No prayer fully expresses our faith. No confession brings perfection. No pastoral visit brings wholeness. No program accomplishes the Church's mission. No set of goals and objectives includes everything. This is what we are about. We plant the seeds that one day will grow. We water seeds already planted, knowing that they hold future promise. We lay foundations that will need further development. We provide yeast that produces far beyond our capabilities. We cannot do everything, and there is a sense of liberation in realizing that. This enables us to do something, and to do it very well. It may be incomplete, but it is a beginning, a step along the way, an opportunity for the Lord's grace to enter and do the rest. We may never see the end results, but that is the difference between the master builder and the worker. We are workers, not master builders; ministers, not messiahs. We are prophets of a future not our own" (emphasis mine). See Ken Untener, "Prophets of a Future Not Our Own," United States Convention of Catholic Bishops, accessed December 20, 2017, http://www.usccb.org/prayer-andworship/prayers-and-devotions/prayers/archbishop_romero_prayer.cfm. 
and ministry degree programs; the interest in theological and ministerial education as the basis for a second career or a career "add-on" among so-called "adult" learners (mid to late thirties and beyond) who overwhelmingly enroll as part-time students; and the list goes on. On the other hand, "between the times" refers to the present as a kairos - a time for the in-breaking of grace between the chronos of what was and the chronos of what will be. ${ }^{4}$

One of the geniuses of this project, however, is that it has identified and taken successful steps to avoid the temptation of assuming that strategies for coping with and adapting to these "earthquakes" in graduate theological education can be developed independent of renewed, deep, and sustained reflection on the very telos of theological education itself. As Antonio Alonso, one of the project coordinators, has recently written:

In the daily stress of finding ways to answer these urgent questions [around institutional change], we can often settle into a managerial mindset in which the larger question of the purpose of theological education is subordinated or even lost. Practical questions are of course crucial. Changing institutional configurations demand our very best management. But these new shifts make old questions about purpose even more vital. Why are we doing this in the first place? What is all of this for? To what end is theological education oriented?5

Another closely related genius of the project is its fundamental conviction that "no single testimony will be fully truthful or comprehensive to the work of answering these questions. Anything like an adequate understanding will require knowledge from multiple perspectives. The pluralism essential to our

4 The classical Greek distinction between kairos and chronos as genres of time is one which has roots in ancient Hellenistic philosophy as well as Pauline Christian theology. I have found the following explanation of kairos as a special genre of time which interrupts the more conventional chronos to be especially helpful: "Time as kairos is the 'point in time' in which that which has no worldly correlation comes to appearance, but that time cannot be known either in advance nor — as it defeats all worldly knowledge — at the time of the coming itself. Only with the eyes of faith can it be encountered. Kairos, though, is not 'contained' in the future; rather it is the moment (Augenblick) between past and future; it is the temporal dimension of decision. In this sense, for Paul, the decision of faith is already living in the kairos." See Felix Ó. Murchadha, The Time of Revolution: Kairos and Chronos in Heidegger (London: Bloomsbury Publishing, 2013), Kindle ed., 14.

5 Emphasis mine. Antonio Eduardo Alonso, "Theological Education Between the Times: Reflections on the Telos of Theological Education" in Religious Studies News (April 28, 2017) accessed December 18, 2017, http://rsn.aarweb.org/spotlight-on/theo-ed/between-the-times/ theological-education-between-times-reflections-telos-theological-education. 
discernment requires diversities of race, ethnicity, gender, sexuality, faith, region, discipline, and vocation." 6

Whatever I identify as the telos of theological education can be nothing more than a "single testimony." And yet, as Alonso implies, the singularity of any one testimony by no means minimizes its potential contribution to a larger plurivocal process of discernment. Hence, without apology, I offer what I advertised as the "rather brash and ethereal flourish" of this first movement: the telos of theological education can be nothing short of resourcing people of all sizes, shapes and colors - people of all faiths and of no faith-for leadership in what the Roman Catholic tradition refers to as the missio Dei or "God's mission." In prophetic terms, this mission is as simple as it is wildly ambitious. It is the work of establishing the shalōm/saläm of biblical and qur'anic revelation - the integrated wholeness of all things that is the original and eternal desire of the Creator for creation.

"Integrated wholeness of all things" is not a bad translation for a quintessentially theological ideal which, through its far more conventional and decidedly more elegant one-word translation as "peace," is so often confused with its shadowy political counterpart. The point here being that, whereas in geopolitical parlance "peace" connotes the absence of overt violent conflict, in theological parlance shalöm/saläm refers to the presence of justice. The problem, however, is that although "integrated wholeness of all things" may be a better technical translation of shalom/salām than "peace," as a response to the question about the missio Dei or the telos of theological education, it is no less abstract and vague than its conventional counterpart. In other words, to say that the purpose of theological education is to resource people for leadership in the pursuit of the "integrated wholeness of all things" is to beg the question: "Yes, but what exactly does the 'integrated wholeness of all things' mean?" To this question, I can offer no definitive answer simply because "the integrated wholeness of all things" can only be arrived at inductively as the ultimate macro goal is pursued in myriad different micro contexts. What I can do, however, is draw on my own micro context and be a bit more specific as to what exactly shalōm/salām entails.

In Barking to the Choir, the much-anticipated sequel to his New York Times bestseller, Tattoos on the Heart, ${ }^{7}$ Greg Boyle ${ }^{8}$ speaks passionately and profoundly of "God's dream." At one point, after relating the story of a "homie"

6 Alonso.

7 Gregory Boyle, Tattoos on the Heart: The Power of Boundless Compassion (New York: Simon and Schuster, 2010).

8 Gregory Boyle is the celebrated founder of Los Angeles's Homeboy Industries—in his own words, "the largest gang intervention, rehab, and reentry program on the planet" (Barking, 3). 
named Gabino, who intuitively grasps what Boyle refers to as "the original program" of the Gospel, the latter writes:

The Choir aims to challenge the politics of fear and the stances that limit our sense of God. It believes that a love-driven set of priorities will ignite our own goodness and reveal our innate nobility, which God so longs to show us. It invites us to inch the world closer to what God might have had in mind for it. And the poor are our trustworthy guides in this. The original covenantal relationship in the Hebrew Bible (the original "original program") went like this: "As I have loved you, so must you have a special, preferential, favored love for the widow, orphan, and stranger." God knows that these folks know what it's like to be cut off. And because they know this particular suffering, God finds them trustworthy to lead and guide the rest of us to the birth of a new inclusion, to the exquisite mutuality of kinship: God's dream come true. ${ }^{9}$

In the subtitle of this new book, Boyle describes the kinship of "God's dream" as "radical," by which he means that the kinship God intends for us human beings is, among other things, "boundless,"10 "total," and "uncompromising" in its inclusivity.

It is no coincidence that these adjectives are also applicable to the very being, will, and compassion, not only of the God of the Bible and the Qur'an to whom Boyle ascribes this sublime "dream." Although Boyle is quite fond of Sufi poets like Hafez and Rumi, he doesn't make much use of the Qur'an. The one reference he does make to the Qur'an, however, is spot on. Supporting his point by citing a verse from Sürat al-Hujurāt which has become a locus classicus for Muslim theological reflection on engagement in interreligious and other forms of intercultural dialogue (Q 49:13),"11 Boyle brilliantly argues that, "It would seem that God created an 'otherness' so that we could find our way in mutuality to kinship. Margins manufactured by God, perhaps, so that we'd dedicate our lives to their erasure."12

9 Emphasis mine. Barking to the Choir, 164-65.

10 The term Boyle uses to describe the "compassion" he references in the subtitle of Tattoos.

11 "O humanity! We have created you from a [single] male and a [single] female and apportioned you into [various] peoples and social groupings so that you might come to know one another. Indeed, the noblest among you in the sight of God is the most Godconscious. For truly God is one who [fully] knows and is [fully] aware."

12 Emphasis mine. Barking, 177. For an expanded analysis of the implicit theology of radical kinship of Q 49:13, see my argument with respect to a qur'anic theology of encuentro in 
Of late, I have been tempted to go a bit farther than Boyle when it comes to my own understanding of what the Qur'an appears to teach about "God's dream" of radical kinship.

There is a pericope in Sürat al-Baqara (Q 2:30-33), the opening verse of which vaguely echoes Genesis 1:26.

The One who nurtures and sustains you (s.) said to the angels: "I am about to install a khalif $f a^{13}$ on the earth." They said: "Will you impose upon the earth one who will spread corruption and shed blood upon her, [when you could install] us - we who glorify you with praise and proclaim your holiness?" [God] replied: "I know what you do not know. And [God] taught Adam all the names. Then [God] placed [every created thing] before the angels and said [to them]: "Tell me their names-if you be [as] prepared for authentic relationship [as you seem to suggest] (in kuntum șädiqin)." They said: "Glory be to you! We know only what you have taught us - you who are the Source of All Knowledge and the Source of All Wisdom." God said: "O, Adam! Teach them their names." And when [Adam] had taught them their names, [God] said: "Did I not say to you (pl.): 'I know the hidden [realities] of the heavens and the earth, as well as what you reveal and what you conceal'?"

It is interesting to note that, with respect to the biblical version of this creation scene in the Genesis passage, there is an exquisite and well-known midrashic tradition which calls attention to what some have found to be the somewhat counterintuitive nature of God's use of the first person plural: "Let us make the human being in our image, after our likeness." This tradition attempts to explain why the one true God would speak as "we" by arguing that it is an expression of the consultative nature of God and even, according to the commentary of Rashi, "the humility of the Holy One, blessed be He."14 According to Rashi,

Scott C. Alexander, "Encountering the Religious 'Stranger': Interreligious Pedagogy and the Future of Theological Education," in Ted A. Smith, Marti R. Jewell, and S. Steve Kang, eds. Theological Education 51, no. 2 (2018): 49-59.

13 Khaliff (often left untranslated and rendered in English as "caliph" when used as the title of those who "succeed" the Prophet Muhammad $s$. as leaders of the umma) is a notoriously difficult term to translate, especially in the case of this particular qur'anic usage. In the context of this pericope, interpretations range from the highly literal "successor" to the jinn as the second species of rational beings to inhabit the earth, to God's "vicegerent" or "vicar" as steward of the sub-lunar realm.

14 Emphasis mine. See the English translation of the Torah accompanied by Rashi's commentary, accessed December 21, 2017, http://www.chabad.org/library/bible_cdo/aid/8165 \#showrashi=true. 
God - generally understood to be the only being ontologically independent of all others-speaks in the first person plural in order to reduce the potential envy of the angels toward the human race, as well as to teach those in positions of authority to act with humility. ${ }^{15}$

Moving back to the qur'anic pericope, what intrigues me is the fact that, although the Qur'an is by no means averse to God's speaking in the first-person plural, that is decidedly not the case here. God speaks in the divine "I" and not the divine "We." As the immediately ensuing pericope having to do with the command to the heavenly hosts to prostrate themselves before Adam appears to suggest, the quranic telling of this critical episode from cosmic history seems to want to explore the very "envy" of the angels that, according to Rashi's interpretation, God hopes to short-circuit. But why and to what avail?

Perhaps a clue lies in the fascinating way in which the Qur'an seems to deliberately invert the use of the first-person plural. In this qur'anic pericope it is the angels who appear to be depicted as the first of the created order to arrogate to themselves "we-ness." God is singular. The khaliffa God is about to "appoint" (i.e., Adam) is singular. The angels are the ones who assert group identity, and more importantly they do so not primarily out of a positive sense of shared kinship, but out of what appears to be naked arrogance and jealousy. Put a slightly different way, they assert their celestial "we" and establish their angelic in-group precisely at the expense of a "threatening" other and the equally threatening out-group of which Adam will undoubtedly be the progenitor. Translated into substantially earthier and colloquial speech, one can almost hear them impiously grouse between the lines of their overtly pious pleas: "What did you say? You're going to do what? Great. Not only are you going to make another one of your playthings who will only end up disappointing and dishonoring you, just like those jinn. (By the way, how'd that work out?) You're going to take it a step further and bestow upon this new muddy 'thing' a place and vocation of honor. And what's worse, you are going to do all this while we who are suffused with supernal light and who have done nothing but praise and exalt you are passed over-yet again?! And you call yourself 'Just'? What a joke!"

God's response is equally fascinating. There is no attempt to reason with the angels, any more than there would be in the case of a wise and seasoned parent dealing with a group of jealous and petulant children. Rather, God answers

15 Rashi: "Scripture did not hesitate to teach proper conduct and the trait of humility, that a great person should consult with and receive permission from a smaller one. Had it been written: 'I shall make [the human being]..., we would not have learned that [God] was speaking with [God's] tribunal, [rather than] to Himself." 
with a simple, "I know what you do not know," followed by a partial demonstration of exactly what God knows that they do not. God asks the angels if they can name all the other beautiful beings of God's magnificent creation. The temptation here is to interpret this as a test of the angels' command of the "created order database." On some level it may be. On a much deeper level, however, asking whether one knows the name of another is far more than a taxonomic quiz. It is a test to see if there is a meaningful relationship in place.

When God asks the angels whether they know the names of the other creatures, God is, in effect, holding a corrective mirror up to the very focus of the angels' implicit boast as the elite and exclusive essence of their "we-ness": their sublime ethereal nature. Although the angels are creatures, they are not creatures of the earth, but of the heavens, and the heavens alone. Thus, although they express "concern" for the earth and its varied created inhabitants, God attempts to show them, in this mirror, that their "concern" for the things of the earth is at best abstract - not at all rooted in an experiential and relational connection with the other creatures - and at worst utterly false and feigned. In either case, their "concern" has little or nothing to do with a genuine desire to be in kinship with the earth and her creatures, and far more to do with the vain self-satisfaction of belonging to their self-made celestial in-group. Adam, on the other hand, knows the names of the creatures precisely because God has created him as the one earthly being with the capacity for being in relationship to every other type of creature, including the angels. I would propose that an evidentiary linchpin for this interpretation may well lie in the fact that the word șädiqin (lit. "righteous ones") comes from the same root as both the words for "charity" (sadaqa) and "friend" (siddīq), and thus that the Arabic in kuntum șādiqin can possibly be translated as "if you be [as] prepared for authentic relationship [as you seem to suggest]."16

That the hubris of the angels and the inherently exclusivist dynamic of their claim to "we-ness" was to be outdone by the very human beings whose progenitor they were divinely commanded to venerate, is undoubtedly the greatest

16 I propose this rather unconventional interpretation based on the highly evocative etymological connections, with respect to the root $S D Q$, between being truthful or authentic, and being in proper and mutually enhancing relationship with others. Note especially the connective tissue between the first form of the root (having to do with speaking the truth); the second form (having to do with recognizing the truth or authenticity of a another); the third form (having to do with acting in friendship with another); and the sixth form (having to do with being true and sincere with one another, usually in affection and love). See, for example, Edward William Lane, An Arabic-English Lexicon, Book I, Part IV (London: Williams and Norgate, 1872), also online, accessed December 29, 2017, http://lexicon.quranicresearch.net/data/14_S/o32_Sdq.html. 
irony of this story. What neither the arrogance of the angels (and Iblis) nor the eventual arrogance of Adam's descendants allows them to realize is that God is the only one who can and does convene a "we" with no "they." All of the "we"s that human beings imagine and construct for ourselves are imperfect and easily coopted for unjust purposes. This is because, in our construction of "we"s, we humans inevitably posit "they"s whom we almost invariably either end up attempting to assimilate, dominate or oppress as unworthy shadows of ourselves, or whom we end up successfully excluding as the objects of our limited compassion and thus futilely attempting to exclude as the objects of God's boundless compassion.

In many ways, this pericope portrays God as teaching the angels a lesson in tawhid - the endless proclamation, in word and deed, of the unrivaled place the sole Creator must occupy at the center of every creature's life. Somewhat paradoxically, even the angels-beings actually hardwired for nothing other than tawhid ${ }^{17}$-have not fully grasped the reality of their own being. Enthralled as they are with their own privileged status as those created to perform the heavenly circumambulation (Ar. tawa âf) around the celestial Ka'ba, they cannot appreciate the fact that the heavenly Ka'ba and what is to be the earthly Ka'ba are but one and the same. They cannot understand that God has destined even creatures of "mud" to join as one with them, albeit on a different plane of existence, in one unitive act of worship with the one God as their sole object of service and devotion. After rehearsing, for Muhammad (s), the history of God's messengers to humanity (vv. 51ff), Sürat al-Anbiy $\bar{a}^{\prime}$ punctuates this retelling with words spoken not just to the Prophet, but to the wider audience of all creatures:

This community of yours (pl.) is one community and I the One who nurtures and sustains you (pl.): worship Me! And [yet] they succumbed to division, [but one day] all will return to Us (Q 21:92-93).18

Note the highly evocative juxtaposition of the divine first-person singular in verse 91 with the divine first-person plural in verse 93. Despite the fact that the divine plan for all creatures to be an undivided "we" in the worship of the indivisible "I" appears to be frustrated by the creaturely devising of so many "they"s, all — without exception—are destined to recognize that there has only ever

17 The technical term is musakhkharāt - creatures who, by nature, obey all of God's commandments without exception.

18 inna hādhihì ummatukum ummatan wāhidatan wa anā rabbukum fa- 'budūni wa taqaț̣a $\bar{u}$ amrahum baynahum kullun ilaynā rāji īùn. 
been, and only ever will be, one community of worshippers gathered in unitive circumambulation around the only "Us" that truly exists—-the "Us" that admits no "they."

To the extent that this interpretation withstands the hermeneutical scrutiny of others-especially of Muslims - one might argue that the periciope of Q 2:30-33 may well hint at a Qur'anic version of "God's dream" of the radical kinship of creation. If so, one might also argue that this very same pericope positions the human being as a critical fulcrum of this kinship. In other words, perhaps we have found here yet another layer of the possible meaning of khalïfa as one who engages in a khiläfa (i.e., "caliphate"), or what Christians typically refer to as a "ministry," of radical kinship. If, at this point, you sense that I am contending that the telos of theological education is to provide a context for human beings to embrace the call to the caliphate of radical kinship for which God created each and every one of us, you would be right.

\section{Part 2. Formation for a Ministry/Khiläfa of Radical Kinship as Interreligious Ally}

One of the new realities that has emerged on the shifting landscape of theological education, like new growth through the fissures of its many fault lines, is what the title of this volume refers to as "interreligious learning" or the practice of educating and being educated interreligiously. I am convinced that, in these early years of the twenty-first century, one of the greatest challenges and opportunities for both theological educator and theology student alike is to be formed as ministers/khulafä' of radical kinship in and through relationships of intellectual exchange, personal trust, and moral solidarity with people of other faiths. ${ }^{19}$

In my experience, this formation happens within the specific framework of striving to be an interreligious ally - a framework which includes many possible contexts. The purpose of the second "movement" of this essay is to attempt to convey just a few samples of what this specific type of theological formation "sounds" like. To do this, I have chosen to reflect briefly on my experiences in aspiring to be an interreligious ally (and inviting others to do the same) in

19 Here I mean to include what Chris Stedman describes as "faitheists" - people who do not affiliate with any tradition and who may indeed reject the existence of God or a transcendent reality, but who nonetheless have a genuine respect for the life of "faith" and who recognize and even affirm the quasi-religious character of their own deep existential commitments. See Stedman's Faitheist: How an Atheist Found Common Ground with the Religious (Boston: Beacon Press, 2012). 
three intersecting contexts. The first is that of formal "classroom" ministry. The second is that of public advocacy. The third is that of a far less formal and far more personal ministry I attempt to exercise on social media.

As a teacher, a great deal transpires in the classroom (be it online or face-toface) by way of participating in the divine-human synergy necessary for creating sanctuaries for dialogic and mutually transformative learning. At Catholic Theological Union (СтU) in Chicago I teach with Muslim colleagues and there are always one, two, or more Muslim students in the various courses we have the privilege of leading. Together we witness-and revel in - the experience of Muslim and Christian students committed to vocations of spiritual leadership in their respective faith communities, working out the shape and content of their vocations in dialogue with one another.

Most recently, this praxis of interreligious team teaching and relationship modeling has opened new and exciting intersectional avenues for student, faculty, and overall institutional transformation. For the past three years, I have partnered with Shamar Hemphill, a Blackamerican Muslim colleague who is a seasoned community organizer for the Inner City Muslim Action Network (IMAN) - an internationally recognized Muslim social service organization pioneering innovative and highly successful projects for social change on Chicago's South Side. ${ }^{20}$ Shamar and I teach a course on "community organizing in interfaith perspective," in which students explore Blackamerican Christian and Blackamerican Muslim liberation theology interspersed with training modules in the practice of faith-based community organizing. At the conclusion of the course, students have the option of pursuing a practicum in which they can realize the community organizing project they propose as one of the requirements for the course. In the first year of the course, students inspired and supported each other as aspiring interreligious allies and developed projects ranging from an interfaith effort to end the practice of witch-camping in Ghana, ${ }^{21}$ to an effort to help communities on Chicago's South Side better understand and provide support for people suffering from mental illness.

The great Franciscan spiritual writer, Richard Rohr, once prophetically observed: "We do not think ourselves into new ways of living. We live ourselves

20 In fact, the executive director of IMAN, Dr. Rami Nashishibi, was awarded a 2017 MacArthur Foundation Award (aka "genius grant") in support of the work of IMAN. For more on IMAN, accessed December 29, 2017, see https://www.imancentral.org.

21 For an introduction to the phenomenon of witch-camping, see Kati Whitaker, "Ghana Witch Camps: Widows' lives in exile," in ввс News Online Magazine, 1 September 2012, accessed December 22, 2017, http://www.bbc.com/news/magazine-19437130. 
into new ways of thinking."22 It was Shamar who has helped guide CTU into a new way of living, which in turn has led the institution to a new way of thinking about its mission and educating its students. He began by inviting us to welcome IMAN to use our facilities for its annual community organizing training. He then moved to inviting me to live a closer relationship and alliance with him and IMAN, which in turn led to our collaboration on the course I just described. Most recently, through his superb efforts as a community organizer, Shamar has played a pivotal role in our securing a generous gift for the Catholic-Muslim Studies Program at CтU from a Muslim family foundation which also supports the mission of IMAN. Because of this gift, CTU has initiated the Beloved Community Internship Program whereby our students are afforded the opportunity to be formed for ministries of radical kinship as they realize their vocation to be interreligious allies for social justice. Key to the vision for this program is that the kinship the interns help build will help стU develop a long-term commitment as an institutional ally of a local South Side neighborhood sorely affected by the legacy of centuries of broken kinship.

My own ministry of public advocacy - particularly in the fight against Islamophobia and the discrimination it breeds-has also been an important medium for my own and my students' formation as aspiring interreligious allies. Emerging out of the praxis of public speaking, primarily in religious congregations and on college and university campuses in the United States and abroad, I have developed a course entitled "Islam and Muslims in a Time of Islamophobia: a Catholic Response." Students learn that great strides can be made toward building communities of radical kinship by engaging in various forms of public advocacy on behalf of communities facing marginalization and even demonization. The intensive and difficult challenge of winning hearts and minds-and thus effecting significant social change-is a long road with many small but cumulatively transformative milestones along the way. Many of these have to do with the relatively simple, but deeply human business of building relationships of trust-each at its own pace and each with its own particular rhythms. Students also learn, however, that it is in this indispensable realm of activist solidarity that the personal cost can be as high as the potential for meaningful social transformation. If there is anything that human beings cherish and need as much as they do the things and the people they love, it is the things and the people they fear.

For whatever reason, it seems that social media is the context in which arise the most unexpected opportunities for the aspiring interreligious ally to

22 Richard Rohr, Everything Belongs: The Gift of Contemplative Prayer (New York: Crossroad Publishing, 1999, 2003), Kindle ed., 19. 
exercise a ministry/khiläfa of radical kinship. These are moments infused with the grace of an awareness that the hand of divine providence is at work in one's ministry/khiläfa. As such, these can also be moments of deep encouragement and affirmation of one's "work in the vineyard" - of its efficacy, of its value, and of its inevitable limitations and fragility. In my own life, these have been those rare moments when years of study and preparation seem to have met with the most precious of opportunities, pregnant with the possibilities inherent in either something as "big" as an entirely new chapter in my ministry, or something as "small" as the simple claim of another human being on me and my capacity to love.

Most recently, such a moment came in the form of my "nephew." When I first met him, he was fifteen going on sixteen. At the time of the publication of this essay, he will likely be nineteen going on twenty. Let's call him "Faysal." I first met Faysal through the "secret" Facebook group I mentioned in the prelude. He sought me out for private conversation. When we finally got past the fact that I was neither gay, nor Muslim — and far too old for the highly problematic and misplaced romantic interest that apparently led him to me in the first place-we began to get to know one another. At my suggestion, he gradually took to calling me "uncle" (then stopped, then started again-adolescents are complicated!) and he eventually became Facebook friends with both my wife and our then twenty-six-year-old son.

I quickly learned that Faysal and his family were among the three-million+ refugees of the Syrian civil war living in Turkey. When we first met, Faysal was deeply self-loathing. He was attending a high school for Syrian refugees sponsored by the Muslim Brothers where, among other things, he was mildly bullied for being "weak," and where he developed a serious crush on one of his male teachers. When he shared this with the teacher, he got a response that I can only describe as similar to what a young Catholic man might receive at a fairly conservative Catholic high school in the United States (or many other places in the world). It entailed notable compassion for Faysal's "plight," mixed with a strong admonition that he should never, under any circumstances, act on his sexual desires-never actually enter a loving relationship with another man lest he fall into "egregious sin." I also learned that he was being medicated for depression, but also that he had been put on a powerful antipsychotic drug for the purposes of controlling his sexual impulses. The drug gave him horrible headaches and caused embarrassing weight gain. Faysal's only solace was in his video gaming and what few meaningful relationships he could establish through Facebook and other online media.

We had extended conversations both via text and face-chat in which I would insist on God's love for him as he is, and he would respond by accusing me of 
being a mustashriq - literally an "orientalist," or in the parlance of a certain strain of Muslim Brotherhood education, a westerner interested in colonizing Islam and the minds of Muslims by liberalizing and secularizing them. All I could say in response to Faysal's accusation was that, in the context of our relationship, I could not care less about "Islam" or "Christianity" per se-only him and the kinship God wants for him. By the same token, however, it was clearly my knowledge of his faith and his tradition that became the foundation of our relationship, and, at least at the beginning, of his trust in me.

As I write this, much has transpired in our relationship and in Faysal's life, including a dangerous and failed attempt to cross the Aegean in the "care" of greedy and inept smugglers. He was accompanied by his sixty-year-old mother and his brother who was seriously injured in the war against Assad. He and his family were among only nine survivors of the fourteen people on the boat, including young children who perished with Faisal unable to do anything to help them. It was a traumatic experience for him, to say the least.

In the way that God always brings moments of great grace and joy out of incidents of human sin and suffering, this ordeal ended up being a blessing for Faysal. As traumatized as he was by the events of the crossing, and by two days spent in a Turkish jail separated from his mother and brother, he has realized that he is not the "weak" and fatally "damaged" human being he had been told he was by his father, his brother, and his teachers for so long. He eventually transferred to a different high school and managed to secure a scholarship for Turkish language study and a computer science degree at a regional Turkish university. Because of the difficulties of his social circumstances as a gay Syrian refugee living in Turkey, Turkish campus life has been particularly difficult for him. For this reason, we have been exploring the possibility of his attending university in either France or Canada. Unfortunately, due to recent changes in U.S. immigration and refugee policy — changes which are designed to corrode even more rapidly and decisively the very fabric of radical kinship - the chances of Faysal settling in the United States with his "aunt" and "uncle" are slim to none.

For my part, I have been incredibly enriched by the grace of Faysal's presence in my life. I have learned more about Japanese video games and anime than I ever thought. I have learned more about the online experiences of a young gay man than I ever wanted. But I have also learned so much about myself and God from this truly old soul masquerading as a teenager. His recent but well-earned distaste for all things "religious" stands in a kind of sublime tension with what I believe is his usually unspoken yet profound awareness of the presence of God in his life. This contrast never ceases to engender in me a sense of awe and privilege to be his "uncle" and ally. On a recent Christmas 
morning, he called me to wish me a "Merry Christmas." As we face-chatted, I asked if he wanted to see the two gifts my wife and I bought for our neighbors' children who, together with their parents, would be joining us for Christmas dinner. His immediate response was to chuckle and say: "Please don't tell me you bought them Qur'ans!" "Oooh, I should have thought of that," I said jokingly. "No, wise guy," I retorted. "We got them stuffed animals." "I see," he said. "You'll get them Qur'ans when they're older." "It's scary how well you know me," I said. "While we're on the subject, when was the last time you made șalāt?" I asked. "Don't start," he said. "It's Christmas—not a time for arguing about whether I should be a good Muslim or not." We both laughed in agreement. After we hung up, I recalled a time when I used to tell him that I loved him and that God loved him. For a few years, his answer was always the same: either deafening silence, or the painfully honest, "I told you I don't know what love is, or who God is. So please don't keep saying this, ok?" Now it is either a warm and slightly sarcastic, "Yeah, I know," or a quiet and only remotely reluctant, "I love you too."

The consciousness of this liminal moment in the history of graduate theological education offers us an opportunity to reflect on the importance of centering theological education, not around a pedagogy of discerning identity and vocation in some imagined center of confessional stability, but rather around a pedagogy of finding one's vocational identity and purpose in the nearly infinite liminal spaces of the limitless fields of the missio Dei. And by "liminal spaces," I not only refer to spaces in which we are used to responding to the call to radical kinship, but also in those relatively new, misunderstood, and unjustly maligned spaces created by digital technology where a fifty-two-year-old straight white Catholic can be an interreligious ally to, and "uncle" for, a fifteenyear-old gay Muslim Syrian refugee.

To make this assertion is not to ignore the importance of "centering" oneself in one's tradition. Rather, it is to emphasize the importance of developing a deep and abiding awareness that all such centers are, more often than not, imaginal and constructed spaces which we heuristically locate as floating islands in a sea of liminality.

In a recent landmark book which pioneers a methodology of "theological reflection across religious traditions, ${ }^{23}$ my colleague Edward Foley borrows a

23 Edward Foley, Theological Reflection across Traditions: The Turn to Reflective Believing (New York: Rowman and Littlefield, 2015). 
term from Lee Hock, the noted entrepreneur who founded the company known today as VISA. The term is "chaordic" and is a neologism hybridized from the words "chaos" and "order." It is an adjective intended to describe frameworks for human creative activity which subvert traditional commandand-control paradigms of organization, paradigms which Hock felt were "antithetical to the human spirit." 24

Foley describes what I have referred to as this distinctly "liminal" moment in theological education not only as "chaordic" in fact, but also as one which requires the embrace of a consciously "chaordic" approach to pedagogy for theological and ministerial education. He does so with great insight and precision.

Somewhat akin to the chaotic changes in business and industry that took place in the late twentieth century, theological education and the many ministries it was designed to serve have also undergone their own revolutions. No longer the exclusive terrain of dominant culture males appointed to well-established congregations, today's seminaries and divinity schools are admitting women in large numbers, some of whom represent growing populations of Jews, Muslims, Buddhists, and even secular humanists. Besides a marked diversity of ministerial students in gender and sexual orientation, ethnic background, and religious identity, the contexts in which such spiritual leaders and chaplains are exercising their service is enormously varied. Steeple churches and other traditional brick-and-mortar settings are giving way to ministries and services variously described as liquid, emergent, experimental, and avant-garde. It is clearly a chaordic age for ministers and chaplains of every stripe. ${ }^{25}$

The epigraph to this essay, to which I promised at the outset that I would return, is the refrain from a track by the popular English indie rock band, Florence + the Machine. The title of the track is "Delilah." The band's riff on the biblical narrative of Samson (Judges 13-16) is highly suggestive of this chaordic mode of theological reflection and education that Foley settles on denoting as "the turn to reflective believing." The lyrics of this song are deceptively theological. The female lead singer, Florence Welch, sings:

Drifting through the halls with the sunrise, Holding on for your call.

\footnotetext{
24 Lee Hock, "The Chaordic Organization: Out of Control and Into Order," World Business Academy Perspectives 9 (1995): 5-18, accessed September 22, 2014, http://www.ratical.org/ many_worlds/ChaordicOrg.pdf. in Foley, Kindle Loc 96/3117. 
Climbing up the walls for that flashing light

I can never let go...

Now the sun is up and I'm going blind,

Holding on for your call.

Another drink just to pass the time,

I can never say no.

Cause I'm gonna be free and I'm gonna be fine,

Maybe not tonight. ${ }^{26}$

On the surface, these words are commonly interpreted as the lament of a woman anxiously awaiting a telephone call from her lover. Perhaps after a one-night stand. But for those familiar with the biblical narrative, it is difficult not to infer that these lyrics are anything less than a reflection-with some significant chaordic twists - on what I would like to propose could be interpreted as discernment for a ministry/khiläfa of radical kinship ("holding on for your call").

Among the twists is the fact that a woman gives voice to the fervent supplication of the legendarily macho Israelite judge-Shimshon, the nazirite "man of the sun," now "blinded" by his passion for justice as his chopped hair begins to grow back. In his hour of discernment and decisive action, Samson is identifying with the courage and strength, not of another male warrior, but of his mother ("And I'm calling for my mother") ${ }^{27}$ - the one originally visited by the angel in what Christians have traditionally understood to be a prefiguration of the Annunciation. All this as s/he stands in that liminal place between the pillars of oppression and proceeds to "pull the pillars down" on her/himself and the Philistines.

And to whom does Samson give credit, after his mother, for this, his greatest act of prophetic courage? He praises, as the source of his last great act of strength, none other than the traditionally maligned prostitute female pagan outsider, Delilah — the ultimate "other" in morality, gender, culture, and cult. The one whom he identifies as his greatest inspiration in the pursuit of ultimate righteousness is the one who otherwise lives in misogynist infamy as the Gazan Philistine cursed for having manipulated his lust and love in order to sap the great Israelite of his strength.

Although the authorized biblical narrative would blame Delilah for his eyes being gouged out by his Philistine enemies, Florence/Samson does not. Instead s/he sings:

26 For the complete lyrics, see "Delilah" by Florence + the Machine on Genius.com, accessed December 29, 2017, https://genius.com/Florence-the-machine-delilah-lyrics.

27 See epigraph. 
Now I'm dancing with Delilah and her vision is mine

Holding on for your call...

...It's a different kind of danger

And the bells are ringing out,

And I'm calling for my mother

As I pull the pillars down.

It's a different kind of danger

And my feet are spinning around;

Never knew I was a dancer

'Til Delilah showed me how

Am I reading a bit too much into this popular rock song? I may well be. But I cannot help being convinced that it evokes, in an almost uncanny way, Foley's call for a turn to reflective chaordic believing in theological and ministerial education - to what I would identify as formation for a ministry/khiläfa of radical kinship as an aspiring interreligious ally. I am convinced that, like this song, theological educators, in this liminal moment, must forge a new chaordic paradigm for theological education which sends a clear message to our students that authentic faith identity cannot ultimately be found, cultivated, and lived out in the allegedly secure spaces of the here or there, the past or the future, the male or the female, the straight or the gay, the Christian or the Muslim. It must be found in the liminal spaces in which stark dualities are softened by a divinely ordained mingling that does harm to neither, but rather illuminates the existence of a mysterious, fearsome, dangerous, exhilarating, creative, and life-giving interdependence between the two.

\section{Bibliography}

Alexander, Scott C. "Encountering the Religious 'Stranger': Interreligious Pedagogy and the Future of Theological Education." Theological Education 51, no. 2 (2018): 49-59.

Alonso, Antonio Eduardo. "Theological Education Between the Times: Reflections on the Telos of Theological Education." Religious Studies News, April 28, 2017. Accessed December 29, 2017.http://rsn.aarweb.org/spotlight-on/theo-ed/between-the-times/ theological-education-between-times-reflections-telos-theological-education.

Boyle, Gregory. Tattoos on the Heart: the Power of Boundless Compassion. New York: Simon and Schuster, 2010.

Florence + the Machine. "Delilah." Genius.com. Accessed December 29, 2017. https:// genius.com/Florence-the-machine-delilah-lyrics. 
Foley, Edward. Theological Reflection Across Traditions: The Turn to Reflective Believing. New York: Rowman and Littlefield, 2015.

Hock, Dee. "The Chaordic Organization: Out of Control and Into Order." World Business Academy Perspectives 9 (1995): 5-18. Accessed September 22, 2014. http://www .ratical.org/many_worlds/ChaordicOrg.pdf.

Jackson, Sherman A. Islam, and the Blackamerican: Looking Toward the Third Resurrection. New York: Oxford University Press, 2005, Kindle edition.

Lane, Edward William. An Arabic-English Lexicon, Book I, Part IV. London: Williams and Norgate, 1872 .

Murchadha, Felix Ó. The Time of Revolution: Kairos and Chronos in Heidegger. London: Bloomsbury Publishing, 2013, Kindle edition.

Rohr, Richard. Everything Belongs: The Gift of Contemplative Prayer. New York: Crossroad Publishing, 1999, 2003, Kindle edition.

Stedman, Chris. Faitheist: How an Atheist Found Common Ground with the Religious. Boston: Beacon Press, 2012.

"Torah." Chabad.org. Accessed December 21, 2017. http://www.chabad.org/library/bi ble_cdo/aid/8165\#showrashi=true.

Whitaker, Kati. “Ghana Witch Camps: Widows' Lives in Exile." BBC News Online Magazine September 1, 2012. Accessed December 22, 2017. http://www.bbc.com/news/ magazine-19437130. 